\title{
Modern Forms of Folk Festival and Folk Cultural Traditions
}

\author{
Ekaterina A. Shchelkina* \\ Khabarovsk State Institute of Culture \\ 112 Krasnorechenskaia Str., Khabarovsk, 680045, Russia
}

Received 14.01.2016, received in revised form 19.02.2016, accepted 18.05.2016

In this article, the author addresses the issue of adaptation of folk festivals and folk cultural traditions to the conditions of modern culture. We consider folk traditions and folk festivals as the artistic and mass action demanding taking into account the specificity of the contemporary cultural situation. By making the holiday understandable and close to modern audience, the organizers will be able to attract the audience's attention to the folk rituals, customs, games, arts and crafts, which reflect the spiritual beauty and the power of the nation; to arouse interest in the folk origins of art and creativity.

Keywords: folk culture, folk festival, tradition, folk music, theatrical directing.

DOI: 10.17516/1997-1370-2016-9-6-1513-1520.

Research area: culture studies.

Modern festival culture includes a large number of remarkable dates and events, which are the basis for creative professionals working in the holiday industry. The events serving the basis for the holiday are diverse: from the private party, where the real actor is one person, up to the public holiday, where group of people, working team, or the population of the whole city, region, and country celebrate. At the same time, two large groups can be divided into among generally celebrated events: the holidays which have been introduced by the state, and celebrations with folk roots of origin, which will be discussed later.

National holiday is based on the centuriesold folk knowledge, has established traditions, certain celebration features. In the festival, in the popular holiday activities men feel as a whole unit, as a nation, as peoples. Coming out of the circle of alienation and limited interests, people feel as if they are the history creators. The long history of the national holiday existence proves its viability and requires a multifaceted understanding and research.

Culture of folk festival educates both an individual person and the whole nation, teaches people the ability to express a sense of solidarity. National holiday cheers people up, focuses the creative energy of masses and expresses the collective emotions. Accumulating these emotions, the holiday reveals real and ideal aspirations of the people. In this situation every man is an artist and a viewer, a creator and a member of special life with their forms of

(C) Siberian Federal University. All rights reserved

* Corresponding author E-mail address: ekate-min@ya.ru 


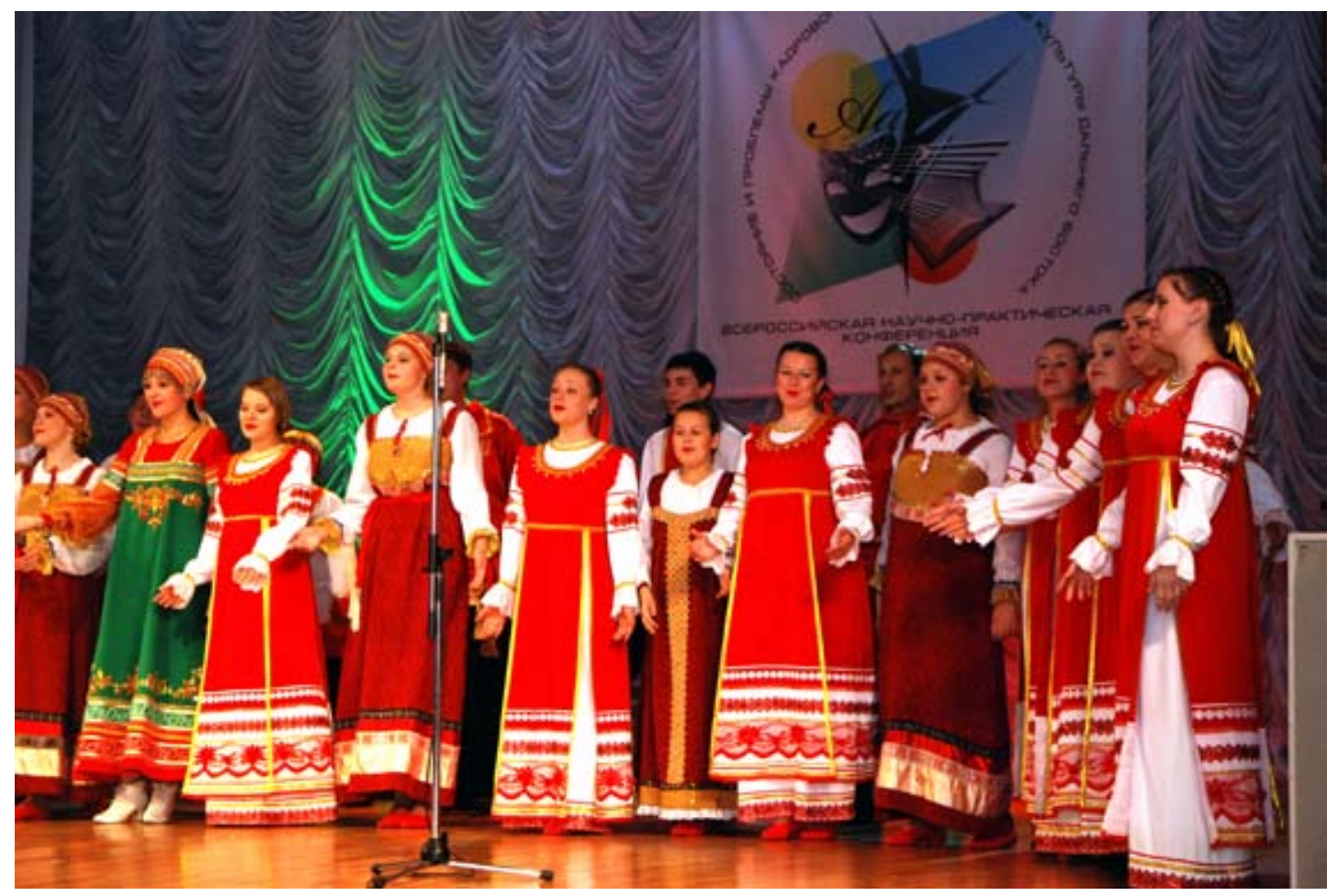

collective behavior, presupposed by traditions, customs, rituals, ceremonies and rites.

Following generally accepted rituals, a person becomes a participant in the festive event. Today, the people feel the urgent need to comply with the rituals, but a modern man is neither competent in ancient rituals, nor aware of the meaning of the word "ritual". Therefore it is necessary to look into this definition.

A ritual is a kind of cultural behavioral code. Namely, a ritual is manifested through behavior; it is the ordered form of behavior in traditional social situations. A holiday ritual is an act of unity and unification of society through formal experience of overall positive emotions and feelings, and awareness of the general importance of the group.

A ritual action is mandatory structural element, a specific feature of any theatrical festive and ritual event, based on folk traditions and folklore. Primary forms of cultural continuity have always been connected with the cult. They exist in order to convey something sacred and in this function the most valuable form of conveying something sacred for members of the community is rituals. They encompass those forms of behavior that are inherently iconic, symbolic and have no utilitarian and practical purpose. Anthropologist M. Douglas defines rituals as the types of activities that are essential for the expression of faith or commitment to certain symbolic systems.

A holiday ritual is a cultural code of the historical, functional and emotional unity of the nation (group), therefore it must be correctly and consciously made by all participants of the ceremony. Rituals are important not by themselves, as they are quite conditional. They become important in what they express. For example, modern audiences cannot imagine Maslenitsa festivities without the popular amusements such as a fistfight, a pillar of ice, baking pancakes, as well as a holiday of Ivan Kupala is unimaginable without weaving wreaths, 
fortune-telling etc. Each of these actions has a deep ritual symbolism, full of meaning, but not all the participants of the celebration know about this meaning. The meaning of many rituals, which disappeared in the late $19^{\text {th }}$-early $20^{\text {th }}$ centuries or which still exist in some game or amusement form, is not clear to a modern man. This is due to the fact that being transmitted from generation to generation, the traditional culture is subjected to strong external civilization interference. The new time brings about certain changes, folk traditions undergo serious transformations and rituals lose the meaning in the society life.

Candidate of Philological Sciences Irina V. Butrimova writes on the problem as such: "A man, learning about events, past actions cannot always understand them or explain. During the evolution customs, traditions and worldview have transformed, and what was clear and understandable, familiar and commonplace for our ancestors a few hundred years ago, is difficult to explain now, from the standpoint of modern man. We do not always know how this or that particular custom began, what oral folk poetry tells us about exactly, what this or that work of folk arts and crafts symbolizes" (Butrimova, 2002).

For thousands of years the traditional folk culture has helped a person to understand the world, nature, people themselves; has adapted a person to life; has remembered, organized and stored knowledge, becoming a source of progress. Folk culture has absorbed and passed on to future generations the moral laws of life, modelling and humanizing the norms of human relations, that is, has formed the spiritual, moral and aesthetic foundations of society.

The urbanization interrupted that living link between the generations, which was the basis for the existence and development of folklore genres. In the early $20^{\text {th }}$ century there was a transformation of people's worldview; the artistic values incorporated traditional forms of folk art and new forms of so-called urban folklore. During this period, there were shifts in the world of aesthetic standards, the social orientation of the culture also changed.

Folk culture has always been connected with the history of the life of the people, with the change of socio-economic formations, so it is constantly developing, evolving, keeping on with the time. At an early stage of development of human society folklore performed mainly logistical and practical function and it was closely linked to human practices. However, this property is preserved in case the traditional lifestyle saved at least partially. But life does not stand still and is constantly updated. As a result, folk traditions, coming into conflict with the new reality, less and less correspond to the household, economic, cultural norms of modernity.

In the process of development, for instance, urban folklore gradually lost qualities, typical of the traditional peasant culture, and finally turned into a spectacle, in which some people are active, while others just watch the action. This spectacle received other than in the countryside, laws of its development; the sacred meaning of the calendar and ritual aspect of the holiday was lost, and folk creativity gradually became professional art.

Today, people's traditional culture is undergoing another transformation in its long and complicated history. There is a rapid growth of national consciousness, interest in the foundations of traditional culture, the revival of handicrafts, crafts and creation of folklore centers. Across the country, regional departments of cultural and leisure activities, arts and crafts carry out the work in the following areas:

- development of organizational and methodological recommendations

- activities of craftsmen houses, folklore and ethnographic groups, clubs of culture institutions 
- raising the level of professional skill of culture officials: seminars, workshops, master classes in arts and crafts and folklore

- research and collecting work

- popularization and promotion of folk art

- conducting mass popular celebrations and exhibitions of folk arts and crafts

Such active promotion of traditional folk art is based on the regulatory framework. Article 23 "State support of folk art" of the "Law on Culture", states: "The state provides support for traditional forms of folk art, folklore, avocational (amateur) art, being the source of formation of national consciousness, a means of preserving national cultural identity and language".

Folk traditions are subjected to serious transformations, but constitute the living fabric of contemporary popular culture. Is it possible to identify universal principles of adaptation of the folk tradition in the modern world and the basic conditions for its survival in the harsh conditions of modern civilization? The main criteria for art understanding is its consistency with the objectives of this era, both in content and form. This requirement can be attributed entirely to the works of folklore, which must also meet the requirements of modern life. Let us look at how the traditional folklore is "modernized" on the basis of music genres:

1. Rethinking the text. In this case the main focus is the emergence of a work with a modern topic, but made in the traditional way, i.e. with modernization of words while retaining the old melody and rhythm. As a result, traditional folklore as if adapts to the changing conditions of life.

2. Re-intonation of tunes. Rethinking and a complete change in the content of the text can entail re-intonation of tunes. In this updated form traditional songs can be included in the orbit of modern folklore.
3. Redefining functions. Folklore responds to changes in the social and public life and reinterpretation of functions, that is, when folklore work passes from one form of existence to another. For example, over time, a song from ritual calendar cycle went away from the ritual and entered children folklore or continued to live, but as a lyric song.

4. The birth of the new modern songs, both in the traditional canons and following new trends. Researchers give them different definitions: household, mass, casual songs, etc. Along with renewed, modernized traditional folklore, musical ethnography has a firmly established concept of folk heritage, which means not so much folklore, as certain examples of folk music, going on to live in the modern everyday life. This folk heritage is taken out of traditional way of life, torn from original folklore function. But some researchers see the positive side in this process of authentic folklore transformation into folk heritage. Firstly, a folk song (and maybe, a rite), performed on the stage or via the information channels, is freed from the specific purpose of life, goes beyond the borders of its own ethnic region and becomes the property of a wider mass of people. Secondly, more active study of traditional folklore in various spheres of modern society gives it a new meaning, turning it into a means of aesthetic pleasure, a source of knowledge of a certain nation.

There is a number of problems in the process of adaptation of folklore material. One of them is the overreliance on folk art "modernization". Sometimes organizers go too far trying to make the material available. We often attend holidays, where folklore is present only in some elements (folk music, Russian nursery rhymes (poteshki), rhymed couplets (chastushkas)), but the basis of the festive action is often far-fetched and has nothing to do with the origin of the holiday or its traditions. 
The organizer of the national holiday faces another important factor - working with creative teams, which use folk genres in its repertoire. It is necessary to consider not only about the purity of the genre and level of professionalism, but also different directions. Some bands literally quote the source, the other, starting from it, create new works. Based on this, all the people's stage folk groups can be classified as follows:

1. The folklore-ethnographic (authentic) ensembles, representing the genuine folklore. Their participants are usually the direct carriers of ancestral traditions, i.e. folklore creators;

2. Folklore groups of the secondary generation, whose participants (both the elderly and young people) may not be the direct bearers of local folklore traditions. However, they perform authentic folk works, adopting them from their carriers and creators of folklore;

3. Folklore groups that use mainly stylized folklore (different arrangements of folk songs).

Each of these groups has its own approach and attitude to folklore, and its way of working with it. The main problem of authentic creative collectives is transfer of the folk song from daily life to the stage, at the same time preserving its main advantages. In addition to this, for folk groups of the secondary generation the main problem is reproduction of the song as precisely as possible to prepare the participants to perceive and reproduce the authentic folk songs, for their further performance on stage. This requires the band leader to know the rules of the local performance, to teach the participants local folklore material, to comply with the main characteristics and features of folklore. In bands, using stylized folklore, the main task of the leader is to emphasize a folk pattern brighter, outlining ways of its emotional impact on the audience. It is relatively easy if the primary source has an interesting "streak" or fresh motif in it. In the author's arrangement of the folklore material, the composer's artistic merit should not be lower than the original source.

One of the most common methods of adaptation of folklore material is the aforementioned stylization. This word means "purposeful reproduction of someone else's style as a certain aesthetic and ideological position in the new art context". The object of stylization is usually stylistic systems, remote in time and space, and not only individual styles, but rather perceived in an extended sense styles of entire eras and national cultures.

Nowadays we regard stylization not only as a conscious imitation of the style, but also as an artistic reproduction of an era in its own ways of expression, with all the characteristic details and modulations. This is a special way to create a very distinctive aesthetic illusion, based on careful study and elaborate imitation. An example in this case is the style of the whole era, with its own peculiar features, characteristics of expression, turns of thoughts and single words. This is the norm of the art stylization, namely flair to the individual needs of the time, rather than to the normative style in general.

Analyzing the method of using folk traditions and folklore in mass celebrations, as well as summarizing the research on the subject, we should distinguish those educational opportunities that give an action a theatrical character, which promotes deeper understanding of the material by a modern man.

Firstly, there is commitment, an organic connection with the life of the Russian people, who appreciate the national traditions and folklore in its ideological and philosophical aspects as introduction in the colourful past, as respect for elders, and as memory of the heroic accomplishments. These motifs are derived directly from the spiritual and aesthetic needs that guide Russian citizens in their daily lives. 
Secondly, used folk traditions and folklore have a stimulatory character, being an organic link to relevant socially useful activity of the masses in the festive and ritual actions.

Thirdly, functional character, specific and definite purpose that bound folk traditions and folklore to certain events of people's lives. Precisely because of this folklore has always been designed for a particular form of the active expression in the festive and ritual actions. This form is inherent in a particular situation and content that helps to express significant and turning point in people's lives by artistic means, to blow off some steam, to get rid of strong feelings and emotions.

The fourth aspect is that folklore has some artistic limitation, a definite form of expression. Considering folk traditions and folklore as an artistic and mass action, we must point out that their life force lies mainly in the aggregate stability and repeatability of the action, both in traditional and in a modernized form. Transmitting the atmosphere of events, folk traditions and folklore actions produce a certain pattern of behavior in relation to the event. Describing this feature in relation to the national ceremony, V.V. Veresaev writes as such: "All the power, the value of ritual in artistic fixedness is that it gives an artistic channel for the manifestation of feelings squeezing the soul up, eliminating the need to search for a different way to express feelings in a moment of strong emotions" (Veresaev, 1926).

The emotional impact of theatrical performance is impossible without reliance on folk traditions and folklore. However, their function is twofold: as meaningful poetic and musical basis and, at the same time, as a traditional ritual action, complemented by new content.

The most common variations of celebrations and ceremonies, in which folk traditions and folklore are the basis for the organization of event and mass action, show that they can be used to involve the audience, to draw it into dialogue, to offer time-honored stereotype of relations and behavior. This active side of folk traditions and folklore, so important to the methods of their use in the script-writing and directorial conception of holidays and rituals, is manifested in the most recurring types of theatrical performance. There folk traditions and folklore are a real channel of the individual's activities.

In the course of the festival there is a place for collective improvisation, which is a spontaneous creative reaction of a person to the celebrated event. This reaction is expressed in choral singing, mass dances and festivals. This is avocational and not organized activity, the need for which has always lived among the people. This activity finds its way in folk forms, which are traditionally characterized by choral and dance impromptu actions. Improvisation figuratively permeates all kinds of folk mass action, giving a momentum to the creation of a huge reservoir of folk song and vast dance repertoire. Improvisational folk art is always arousing and therefore can be used to express feelings, attitude to this or that event. All these factors make the choral or dance improvisation an essential structural element of the folk celebration action. Writing a script for theatrical ritual act calls on the person responsible to know and understand the subject, which is a ritual as a form of traditional folk culture.

Dramaturgy and directing in festive and ritual theatrical action are complex and timeconsuming processes. While writing a script of the literary folk festival one should consider the traditions and rituals, which are specific only for this holiday, take into account the corresponding regional characteristics, and others. B making a holiday understandable and close to the modern audience, the organizers will be able to attract the audience's attention to the folk rituals, customs, games, arts and crafts, which reflect the spiritual beauty and the power of the people. Thus, the 
organizers will have the chance to arouse interest in the folk origins of art and creativity. Following the canons of traditional culture develops a sense of dignity and national pride, promotes awareness of the special national role in the world civilization.

During the holiday the organizers must provide everyone with the opportunity to find out more about people's creativity, for example, to learn movements of a simple folk dance, to chant the motif of a new folk song. Folklore festival is to show that despite the urbanization of our life, folk art does not die; rather it is saved and developed. Careful use of folklore should be inherent in all creative arts, as well as performative ones, which preserve and develop folk traditions.

So, when writing a script dedicated of a national holiday, which includes certain rites and ritual actions, on should pay attention to certain significant transformation of the holiday both in time and in people's minds. Currently reproduction of the holiday in the form in which it took place a hundred and more years ago is impossible, because there was no any holiday script at the time, moreover, it was not required.
All ritual acts took place in accordance with the custom prevailing for a long time.

Today, there is no point in script writing of the holiday in its original form, it is much better to organize a theatrical performance on the theme of this holiday, because "it is impossible to enter the same river twice". It is unattainable to tell about the traditions and rites in general, etc, while celebrating a national holiday, which has a particular festive situation at its core, which causes certain personal associations. A combination of informative, promotional, emotional and imaginative aspects of the theatrical performance while searching for the characters this folk action, no doubt, must be based on the relation of the peoples of the traditional culture to the nature. From olden times this relation has been based on a kind of the real "agreement", because people have perceived the nature as a partner with whom a dialogue is possible. Acknowledging the magical essence of this "agreement model", we shall conclude that this model can involve eager participants in theatrical performance based on folk traditions and folklore.

\section{References}

Butrimova, I.V. (2002). Kalendarnaia obriadovaia poeziia Orlovskogo kraia: Zhanry. Poetika. Sovremennoe bytovanie [Calendar ritual poetry of Orlovsky region. Genres. Poetics]. Dis. kand. ... filolog. nauk [Dissertation for Candidate of Philological Sciences]. Orel, 3.

Materialy konferentsii "Fol'klor narodov Rossii na sovremennoi stsene" [Proceedings of the Conference "Folklore of the peoples in Russia on modern stage"]. Astrakhan, 2003. Available at: http://www.astrasong.ru/index.php/science/article/373/

Materialy seminara "Adaptatsiia narodnoi traditsii $k$ sovremennym gorodskim usloviiam" [Proceedings of the seminar "Folk tradition adaptation to the modern urban conditions"]. Moscow, MDN, 2011. Available at: http://www.mdn.ru/cntnt/meropriyatiya/archive/n5725.html

Veresaev, V.V. (1926). K khudozhestvennomu oformleniiu byta (ob obriadakh: starykh v novykh) [On artistic design in everyday life (on the rituals: old and modern)], In Krasnaia nov' (Krasnaya Nov). $1,159-160$. 


\section{Современные формы народного праздника \\ и народных культурных традиций}

\section{Е.А. Щёлкина}

Хабаровский государственный институт культуры Россия, 680045, Хабаровск, ул. Краснореченская, 112

В предлагаемой статье автор обращается к проблеме адаптаџии народных праздников и народных культурных традиций к условиям современной культуры. Рассматриваются народные традиции и народные праздники как художественно-массовое действие, требующее учитывания специфики современной культурной ситуации. Сделав содержание праздника понятным и близким современному зрителю, организаторы смогут привлечь внимание зрителей к народным обрядам, обычаям, играм, декоративно-прикладному искусству, в которых отражается духовная красота и сила народа, пробудить интерес к фольклорным истокам искусства и творчества.

Ключевые слова: народная культура, народный праздник, традиция, музыкальный фольклор, режиссура театрализованного действа.

Научная специальность: 24.00.00 - культурология. 